\title{
Reform and Research of the Teaching of Power System Analysis
}

\author{
Zheng Huang \\ Electrical Engineering College \\ Guizhou Institute of Technology \\ Guiyang 55003, China \\ huangz888@163.com
}

\begin{abstract}
The curriculum of power system analysis is an important basic course of electrical engineering, which has action of connecting link between the preceding and the following. In order to adapt to the rapid development of power industry, deepening the reform of education teaching, the paper presents teaching reform measure in the following aspects: Optimizing the teaching contents, improving teaching methods, strengthen the training of the practical teaching link. The method has proved effective in practice.
\end{abstract}

Keywords-power system analysis; teaching reform; teaching method

\section{INTRODUCTION}

The course of power system analysis is a basis for the students of electrical engineering. It plays a bridge between the past and the link role in the entire curriculum system, and is the basis for the follow-up "Electrical Part of the Power Plant", "Relay Protection" and "High Voltage Technology" courses. The course is a key for the students to open the treasure of the electric power system. The course of electric power system analysis has the characteristics of wide content, complex formula, many concepts, and complex calculation and so on. Many students are terrified of it.

With the rapid development of electric power industry and the deepening of education and teaching reform. There is a big gap between the application of power system analysis and personnel training. There are a lot of urgent need for reform and construction of power system analysis course. This article has carried on the reform from the course teaching system, the teaching method, the practice link and so on.

\section{INTEGRATION OF TEACHING CONTENT, TO BUILD AND OPTIMIZE THE CURRICULUM SYSTEM}

Combining the teaching experience of "Power System Analysis" and the orientation of the course in the discipline, according to "optimize the curriculum theory, strengthen engineering education" principle, the teaching hierarchical curriculum system is reconstruction shown in Fig. 1.

The contents and functions of different teaching contents in power system engineering are as follows: the cognitive hierarchy, the theoretical foundation, the analytical application layer and the extension and improvement stratum. According to the status and function of different teaching contents in power system engineering, the four level course content systems are constructed, including cognitive level, theory level, and application level and improving level. Carry out the corresponding teaching for each level

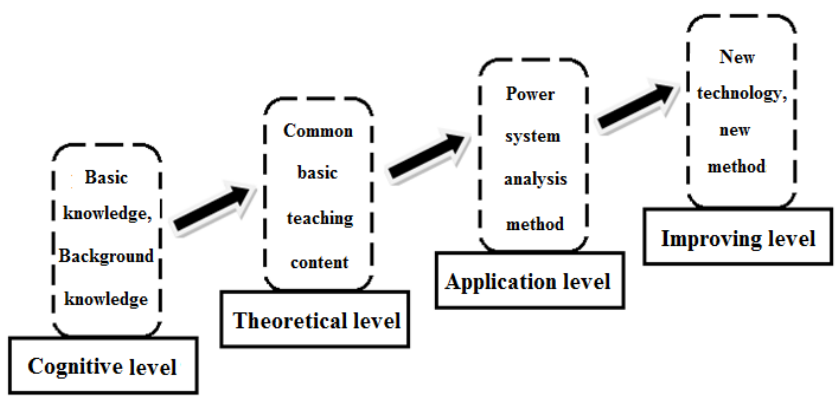

Fig. 1. "power system analysis" teaching hierarchical curriculum system

The teaching objectives and teaching methods of the course at different levels are shown in Table 1. Cognitive level-the perceptual knowledge of the basic concept of the electric power system for beginners, including the composition of the power system, the concept of the power grid, load, and the coordination of the electrical equipment rated voltage. Theoretical level - the characteristic and mathematical model of each component in electric power system. Application level-short circuit calculation and power flow calculation. The basic methods of frequency modulation, voltage regulation, stability analysis and economic analysis are included.

Improving level-new theory and new technology of electric power industry.

TABLE I. TEACHING OBJECTIVES AND TEACHING METHODS OF EACH LAYER

\begin{tabular}{|l|l|l|}
\hline Level & $\begin{array}{l}\text { Teaching } \\
\text { objectives(Knowledge / } \\
\text { ability) }\end{array}$ & Teaching method \\
\hline $\begin{array}{l}\text { Cognitive } \\
\text { level }\end{array}$ & $\begin{array}{l}\text { Basic Composition and } \\
\text { Concept of Power System }\end{array}$ & $\begin{array}{l}\text { Video, on-site visits and } \\
\text { classroom instruction }\end{array}$ \\
\hline $\begin{array}{l}\text { Theoretical } \\
\text { level }\end{array}$ & $\begin{array}{l}\text { Characteristics and } \\
\text { Mathematical Model of Power } \\
\text { System Components }\end{array}$ & $\begin{array}{c}\text { Animation, classroom } \\
\text { instruction }\end{array}$ \\
\hline $\begin{array}{l}\text { Application } \\
\text { level }\end{array}$ & $\begin{array}{l}\text { Knowledge and ability of } \\
\text { analysis and calculation }\end{array}$ & $\begin{array}{l}\text { Simulation, design } \\
\text { engineering examples }\end{array}$ \\
\hline $\begin{array}{l}\text { Improving } \\
\text { level }\end{array}$ & $\begin{array}{l}\text { New technology and theory of } \\
\text { power system }\end{array}$ & Discussion, small papers \\
\hline
\end{tabular}




\section{IMPROVING TEACHING METHODS AND MEANS, HIGHLIGHT THE CHARACTERISTICS OF THE PROJECT}

To learn a course, first of all is to enhance the learning interest and enthusiasm of the course. Take the following measures in teaching:

\section{A. Combined with the engineering practice, enhance students' learning interest and learning enthusiasm}

Students contact with the power system knowledge for first-time, teacher's curriculum design and teaching guidance is very important to develop students' interest in learning. We can let the students are familiar with the working environment and enhance the learning desire by looking at the general situation of the electric power system and the flow of the production line.

\section{B. Simplifying teaching of mathematical model of power system components}

The entire power system is actually a complex circuit system. The power system analysis is the application of advanced mathematics and circuit theory in power system, which covers the electrical engineering, electromagnetic field knowledge. Therefore, this course has a lot of theoretical knowledge, mathematical model is complex and abstract, and the formula is cumbersome. It is suggested that the emphasis should be put on the understanding and mastering of the basic physical process, which can be applied to the formula and reduce the derivation of the formula, to avoid making students into the tedious formula and mobilize the enthusiasm of the students to learn the power system analysis.

\section{Using of problem-solving teaching methods to increase interaction between teachers and students}

Using to ask questions, analyze problems and solve problems as the main line throughout the classroom [1-3].he key of this kind method is to mobilize the enthusiasm of the students to solve the problem, to make students get more sense of accomplishment. Teachers need to set the problem carefully before class. Students can focus on learning around the problem, which is helpful to cultivate students' ability of active thinking, but also can greatly improve the efficiency of learning. For example, for the content of the original flux equation of synchronous motor, we can guide students to observe the problem that the matrix is a variable coefficient, and solve the problem by leading to the idea of park coordinates transformation. Clear thinking can be deepened students to understand the content of the park transformation.

\section{Modern Multimedia Teaching}

It is advantageous to understand the concept and process of the power system which is difficult to be expressed for students by making vivid FLASH animation and multimedia courseware. For example, the introduction of the corona phenomenon, the traditional text is difficult to explain, and through the video is more clear, students can also understand its hazards.

\section{E. Building power system analysis network school}

Make full use of the advanced online network teaching platform built by the school, which let students can easily share all kinds of video, graphics, audio and other learning materials and the use of a variety of auxiliary learning tools. Interactive learning through the network course discussion area, the teacher's question answering, promote the communication between teachers and students, enhance student communication, and improve their learning interest.

\section{CONSTRUCTION OF EXPERIMENTAL TEACHING}

In order to strengthen students' practical ability and innovation ability, and deepen their classroom teaching contents, the experimental teaching links of our power system analysis course include curriculum experiment, curriculum design, and production practice.

\section{A. Course Experiments}

The course of power system analysis is get in touch with the power system for the first time for students. The quality of the mastery is critical to the future professional study. Therefore, the focus of the course experiment is to "lay a solid foundation", and design a multi-level verification, design and comprehensive experimental project for different students. We adopt the teaching, learning, doing the integration of experimental teaching methods. Hands-on experiments is enable students to enhance the practical ability for engaging in power grid operation, but also to train students to solve the problem of logical thinking in the experiment.

\section{B. Course Design}

Curriculum design is an important link of engineering students in university. It is a transition from the basic routine experiments to the graduation design. It requires students to design a simple and reasonable power system after the course with 1-2 weeks' time. The content mainly involves the power system three big computation (power flow computation, shortcircuit computation, and stable computation). Through the curriculum design, the analysis and calculation of a practical system can be carried out, and the knowledge points of each course will be strung together to enhance the cognitive concept of the whole power system. It is helpful for students to integrate knowledge.

\section{Production Practice}

Production practice is an important practice link of higher engineering education, which helps to enhance the engineering consciousness of engineering students [4-5]. Usually adopt the university-enterprise joint training mode, the organization of students to visit the power station and a substation, to employ electrical enterprise experienced professional and technical personnel to guide teaching and practice. At the production site, students can observe the operation of the power grid by power flow chart. It is beneficial for students to combine classroom teaching with production practice, and deepen the understanding of power system. 


\section{CONCLUSIONS}

Power system analysis is the core course of electrical engineering and automation. It has the characteristics of strong theoretical and practical connection with engineering practice and occupies a very important position in the professional curriculum system. In view of the orientation of our university training and the need of the development of electric power industry in our country, this paper makes a deep research on the integration and optimization of the teaching content system, the improvement of the teaching method and the strengthening of the practice, and obtains good results. In order to better promote the course construction, and effectively lay the foundation for improving the quality of personnel training.

\section{ACKNOWLEDGEMENT}

This research was financially supported by Guizhou province colleges and universities teaching contents and curriculum system reform project (Grant No. 201437802) and the key reform projects of Guizhou institute of technology (Grant No. 20131007)

\section{REFERENCES}

[1] Zhao Huang, Long fu Luo. The construction of the teaching system of electric power system analysis course[J]. Journal of Electrical \& Electronic Education, 2013,35 (1) 47-48.

[2] Yan Gao, Yun bo Zhang. Teaching Reform of Power System Analysis for Electrical engineering [J]. China Electric Power education2013, (20):52-53

[3] Mei lian Zhao,Yue Chen. Application analysis of the integrated teaching method in the course of power system analysis[J]. China Electric Power education,2011,(6)76-77.

[4] Jiang Ning iang, Application of Problem directed Method in Teaching "Power System Analysis"[J]. JOURNAL OF EEE2006, (28): $42-45$;

[5] Bing Li. Design of the practice teaching of the course of "power system analysis"[J]. China Electric Power education2013, 2008, (20):134-135. 